\title{
OPTIMALISASI DASHBOARD ANALYTICS DAN IKLANKU SHOPEE SEBAGAI STRATEGI PENJUALAN ALAT DAN PERLENGKAPAN DAPUR SECARA ONLINE
}

\author{
Tresna Maulana Fahrudin ${ }^{1 *}$, Made Hanindia Prami Swari ${ }^{1}$, Risnaldy Novendra Irawan ${ }^{1}$, \\ Nine Alvariqati Varqa Ansori ${ }^{1}$, Nabila Rizky Amalia Putri ${ }^{1}$ \\ ${ }^{1}$ Universitas Pembangunan Nasional Veteran Jawa Timur, Surabaya, Indonesia \\ *tresna.maulana.ds@upnjatim.ac.id
}

\begin{abstract}
Abstrak: Pandemi Covid-19 yang melanda dunia sejak awal tahun 2020 memberikan dampak besar pada sektor perdagangan. Beberapa pedagang di pasar tradisional mengalihkan strategi penjualannya ke model hybrid dengan memanfaatkan marketplace Shopee untuk bertahan di masa pandemi tersebut. Namun demikian, strategi yang dilakukan para pedagang hanya sebatas pada mengunggah foto dan deskripsi produk serta menunggu datangnya pembeli di marketplace sehingga belum mendapatkan hasil penjualan yang optimal. Berdasarkan permasalahan tersebut, kegiatan pengabdian kepada masyarakat ini bertujuan untuk memberikan pendampingan terkait berbagai strategi dan terobosan untuk mengeksplorasi dan menentukan strategi penjualan melalui analitik data, riset pasar, segmentasi pemasaran produk, advertising produk, dan analisis peninjauan performa advertising. Strategi ini dilakukan melalui penggunaan dashboard analytics dan advertising produk menggunakan Iklanku yang disediakan oleh marketplace Shopee. Metode kegiatan ini berbasis Participatory Action Research (PAR) dengan menggunakan dua pendekatan yaitu penyelesaian masalah (problem solving) dan peran serta (participatory). Tahapan program yang dilaksanakan memuat identifikasi masalah mitra, perencanaan kegiatan, pelaksanaan dan pendampingan kegiatan, peninjauan dan evaluasi kegiatan. Hasil kegiatan ini menunjukkan mitra memiliki keterampilan dalam mendeteksi kemiripan produknya dengan produk kompetitor di marketplace Shopee dengan menggunakan metode riset produk. Metode advertising produk menggunakan Iklanku marketplace Shopee juga dapat meningkatkan jangkauan produk mitra kepada pelanggan secara signifikan dibandingkan tanpa menggunakan fitur iklan. Selain itu, dashboard analytics dan statistik iklan dapat membantu untuk meninjau jumlah pengunjung, jumlah klik, dan persentase klik pengunjung hingga mencapai 5,99\%. Rekomendasi dari pelaksanaan kegiatan ini adalah mitra perlu untuk mengatur harga produk yang kompetitif, deskripsi produk yang jelas, klaim kualitas produk, variasi produk yang ditawarkan dan menentukan besaran saldo iklan untuk mempromosikan produk pada marketplace Shopee.
\end{abstract}

Kata Kunci: Dashboard Analytics, Iklanku Shopee, Strategi Penjualan, Toko Sumber Rejeki, Pasar Kota Gresik

Abstract: The Covid-19 pandemic that has hit the world since the beginning of 2020 has had a
major impact on trade sector. Some sellers in traditional markets already have a hybrid selling
strategy by utilizing Shopee marketplaces to survive this pandemic. The problem is that the
marketing strategy carried out by online sellers is not enough to just upload photos and product
descriptions or just wait for buyers because these strategies have not produced optimal results.
Based on these problems, this community service program is aimed at providing assistance
regarding various strategies and breakthroughs to explore and determine sales strategies through
data analytics, market research, product marketing segmentation, product advertising, and
advertising performance review analysis. This strategy can be done through the use of an
analytics dashboard and product advertising using Iklanku provided by Shopee marketplace. A
participatory action research was used in this community service program with two main
approaches; problem solving and participation. The program implemented includes identification
of partner problems, activity planning, implementation and assistance of activities, monitoring
and evaluation of activities. The results of this program show thatpartners have skills in detecting
the similarity of their products with competitors in the Shopee marketplace by using product
research methods. The product advertising method using Iklanku Shopee marketplace that has
been practised can significantly increase products reach to customers compared to without using
advertisement features. In addition, the analytics dashboard and advertising statistics can help
review the number of visitors, the number of clicks, and the percentage of visitor clicks up to 
Fahrudin, T.M., Swari, M.H.P, Irawan, R.N., Ansori, N.A.V., Putri, N.R.A. Optimalisasi dashboard analytics...

5.99\%. Recommendations for the activities are that partners need to set competitive product prices, make clear products' descriptions, claim products' quality, offer product variations, and determine the amount of advertising balance to promote products on the Shopee marketplace.

Keywords: Dashboard Analytics, Iklanku Shopee, Selling Strategy, Sumber Rejeki Shop, Gresik City Market

\section{Pendahuluan}

Sejak awal tahun 2020 lalu, dunia dikejutkan dengan mewabahnya pandemi Covid-19 yang banyak merubah tatanan kehidupan manusia. Pandemi ini telah merenggut banyak nyawa, membuat banyak sektor menjadi lumpuh, bangkrutnya usaha dan menuntut manusia berdiam diri di rumah dan menjalankan protokol kesehatan untuk memutus rantai persebaran virus (Astuti, Hulaify, \& Budi, 2019). Salah satu sektor yang paling terdampak akibat eksistensi virus ini adalah pada bidang perdagangan (Amri, 2020), khususnya bagi pedagang kecil yang melakukan kegiatan jual beli secara offline. Berdasarkan data dari Kemenkop UKM sekitar 37.000 UMKM memberikan laporan terkena dampak serius akibat pandemi ini yang ditandai $56 \%$ penjualan menurun, $22 \%$ melaporkan permasalahan pada aspek pembiayaan, $15 \%$ pada permasalahan distribusi barang, dan 4\% melaporkan kesulitan mendapatkan bahan baku mentah (Pakpahan, 2020). Keadaan ini juga berdampak dengan adanya Peraturan Menteri Kesehatan No. 9 Tahun 2020 tentang pedoman Pembatasan Sosial Berskala Besar (PSBB) dan Surat Edaran Menteri Perdagangan Republik Indonesia Nomor 12 Tahun 2020 yang mengatur kegiatan aktivitas perdagangan yang dilakukan pada masa pandemi dan new normalyang membatasi jam operasional pedagang dan membatasi jumlah kapasitas orang yang beraktivitas pada tempat perdagangan hanya sebesar $30 \%$ dari kapasitas yang ada (Kementerian Perdagangan, 2020). Peraturan ini tentunya berimbas cukup parah kepada pedagang kecil karena pangsa pasar semua bidang usaha UMKM akan sangat ditentukan oleh pergerakan manusia sebagai konsumen (Sugianti \& Sitorus, 2021).

Sebagian besar pedagang yang berjualan di pasar merupakan pedagang kecil yang begitu melekat dengan slogan "hari ini untuk hari esok" yang bermakna kebutuhan mereka besok terpenuhi jika kerja hari ini. Namun, ironisnya pasar tradisional merupakan tempat publik yang paling sering dikunjungi dan memiliki resiko untuk terpapar virus yang cukup tinggi (Supriyadi, Istanti, \& Erlita, 2021). Hal tersebut mengakibatkan masyarakat menjadi enggan untuk berbelanja ke pasar terlebih pasar tradisional dengan alasan keamanan (Panjaitan, Katiandagho, \& Pangemanan, 2021). Potret lingkungan pasar tradisional, pasar rakyat dan pasar kota yang terkadang dinilai pengunjung kurang bersih, padat, berdesakan dan rawan akan terjadinya tindakan kejahatan serta ditambah kondisi pandemi Covid-19 semakin membuat lesu aktifitas penjualan bagi pedagang (Soba, 2020).

Pandemi yang tak kunjung usai meski sudah melanda lebih dari setahun terakhir ini semestinya membuat masyarakat harus berinovasi agar mampu bertahan bahkan meningkatkan eksistensinya (Rosmadi, 2021; Soetjipto, 2020). Salah satu upaya yang cukup berhasil diterapkan dalam mengatasi kelesuan penjualan akibat menurunnya jumlah pengunjung pasar tradisional adalah dengan beralih ke metode pemasaran hybrid. Metode ini mengadopsi perkembangan 
teknologi informasi melalui penjualan online melalui marketplace yang marak berkembang belakangan ini. Bank Indonesia mencatat jumlah transaksi jual beli di perangkat elektronik meningkat hampir dua kali lipat pada masa pandemi ini. Bahkan, salah satu platform marketplace terbesar di Indonesia, yakni Shopee mencatat kenaikan transaksi di kuartal 2 (Q2) 2020 naik $130 \%$ dibandingkan periode yang sama pada tahun sebelumnya, hal ini menjadi indikasi positif bagi ekonomi digital Indonesia, terutama marketplace yang dinilai dapat menjadi penyokong pemenuhan kebutuhan masyarakat dan penggerak ekonomi selama masa pandemi (Timorria, 2020). Pada kuartal 3 (Q3) tahun lalu, jumlah pengunjung Shopee adalah 55,9 juta orang sementara tahun ini jumlah pengunjungnya mencapai 96,5 juta atau meningkat sekitar $72 \%$ (Maulana, 2021). Jumlah ini tentunya menjadi pangsa pasar yang sangat potensial bagi pedagang untuk memperluas pemasaran produknya.

Trend positif ini tentunya sudah diamati oleh masyarakat luas, khususnya masyarakat yang menjalankan bisnis di dunia perdagangan. Hal ini terbukti dengan meningkatnya jumlah toko yang mendaftarkan tokonya di platform marketplace, terutama bagi generasi milenial yang telah melek teknologi (Rakib, Syam, Marhawati, \& Dewantara, 2020). Berbagai macam strategi dapat dilakukan untuk membuat diversifikasi produk yang mampu merangsang peningkatan penjualan produknya. Berbanding terbalik dengan pedagang tradisional yang belum terlalu fasih dalam beradaptasi dengan gempuran teknologi informasi (Wiryawan, Putra, \& Dewi, 2019), hal ini menyebabkan pedagang-pedagang tesebut belum memiliki strategi dan terobosan untuk menarik minat pengunjung marketplace untuk berbelanja di lapak yang mereka pasarkan, terlebih tentunya pada marketplace yang sama terdapat banyak pedagang yang menjual barang serupa.

Toko Sumber Rejeki Pasar Kota Gresik menjadi mitra kegiatan Pengabdian kepada Masyarakat-Pemanfaatan IPTEKS bagi Masyarakat (PIKAT) pada kesempatan ini. Toko tersebut telah beroperasi selama 30 tahun dan menjual berbagai kebutuhan peralatan rumah tangga. Sebelumnya, potret Pasar Kota Gresik masih beralaskan tanah dan becek jika terguyur hujan. Namun, telah dilakukan revitalisasi sekitar tahun 2008 sehingga lantai berubin dan terdiri dari stan-stan lebih layak untuk ditempati. Stan Toko Sumber Rejeki ini juga cukup memiliki ruang yang lebar (berbentuk $L$ ), barang dagangan yang mereka tawarkan tertata rapi menghadap pada 2 sisi pengunjung. Toko ini sudah memanfaatkan marketplace dalam melakukan pemasaran. Namun, berdasarkan data penjualan yang diberikan, didapatkan informasi bahwa strategi pemasaran online yang dilakukan belum membuahkan hasil yang optimal. Hal ini dikarenakan cukup banyak penjual yang menjual barang serupa dengan tampilan lebih menarik, harga barang lebih murah dan cukup kompetitif.

Jika ditelaah lebih dalam, seharusnya strategi pemasaran yang dilakukan para pedagang online tidak cukup hanya mendaftar dan menunggu pembeli pada marketplace. Berbagai strategi dan terobosan dapat dilakukan untuk mengeksplorasi dan menentukan strategi penjualan melalui analitik data, riset pasar, segmentasi pemasaran produk, advertising produk hingga analisis peninjauan performa advertising produk. Strategi ini dapat dilakukan melalui penggunaan dashboard analytics dan advertising produk yang disediakan marketplace Shopee. Selain itu, pendekatan yang diadopsi dalam kegiatan ini berbasis PAR (Participatory Action Research) menggunakan dua pendekatan yang paling sesuai dengan mitra yakni penyelesaian masalah 
(problem solving) dan peran serta (participatory). Dalam proses pencarian mitra, tim Pengabdian kepada Masyarakat mendatangi stan mitra pedagang pasar Kota Gresik dan melakukan identifikasi melalui wawancara. Selanjutnya, mitra diberikan pendampingan secara daring maupun luring, praktik penggunaan aplikasi marketplace Shopee khusus penjual, peninjauan dan evaluasi.

Berdasarkan permasalahan di atas, kegiatan Pengabdian kepada Masyarakat ditujukan untuk peningkatan pengetahuan IPTEKS bagi pedagang di Pasar Kota Gresik melalui kegiatan pelatihan dan pendampingan pemanfaatan aplikasi dashboard analytics dan advertising produk melalui marketplace. Salah satu big marketplace di Indonesia yang cukup dikenal oleh masyarakat dan pengguna yakni Shopee sebagai strategi promosi penjualan produk (Amaludin, 2020). Melalui kegiatan Pengabdian kepada Masyarakat ini diharapkan pedagang yang selama ini belum mengetahui dan menerapkan aplikasi tersebut dapat memanfaatkannya sehingga mendapatkan pengetahuan mendalam tentang pemanfaatan marketplace yang berimbas positif pada peningkatan penjualan produknya serta optimalisasi strategi penjualan produk melalui marketplace.

\section{Metode}

Rangkaian kegiatan Pengabdian kepada Masyarakat ini dilakukan berdasarkan permasalahan yang dialami oleh mitra. Seperti yang dijelaskan sebelumnya bahwa Toko Sumber Rejeki Pasar Kota Gresik telah memiliki toko pada marketplace Shopee. Namun, toko tersebut belum optimal dan belum mencapai target pelanggan yang sesuai yakni berbelanja kebutuhan peralatan rumah tangga. Kegiatan Pengabdian kepada Masyarakat ini bertujuan untuk memberikan edukasi kepada pemilik Toko Sumber Rejeki Pasar Kota Gresik guna mengoptimalkan penjualan produk melalui fitur-fitur yang telah disediakan oleh marketplace Shopee.

Pendekatan yang diadopsi dalam kegiatan ini berbasis PAR (Participatory Action Research). Sebelumnya, mitra yang terlibat dalam kegiatan Pengabdian kepada Masyarakat ini merupakan hasil dari penyaringan berdasarkan wawancara dan pengamatan langsung. Lalu, kajian PAR diaplikasikan menggunakan dua pendekatan yang paling sesuai dengan mitra yakni penyelesaian masalah (problem solving) dan peran serta (participatory). Program yang dilaksanakan memuat identifikasi masalah mitra, perencanaan kegiatan, pelaksanaan dan pendampingan kegiatan, monitoring dan evaluasi kegiatan (Muhtarom, 2018). Hasil akhir dari kegiatan ini diharapkan mitra mampu mengoptimalkan strategi penjualannya dengan memanfaatkan fitur-fitur yang telah disediakan melalui marketplace. Selain itu, bagi mitra lain yang belum melakukan penjualan secara hybrid diharapkan segera mengubah strateginya untuk menjual produk secara offine maupun online agar mampu bersaing di era penjualan produk berbasis digital yang masif saat ini.

Kegiatan Pengabdian kepada Masyarakat ini diselenggarakan dalam dua sesi, di sesi pertama, materi yang disampaikan membahas tentang riset pasar dan segmentasi pemasaran produk pada marketplace Shopee. Di sesi kedua, materi yang dibahas tentang advertising produk, peninjauan dan peningkatan performa iklan pada marketplace Shopee. Selain itu, peserta yang 
diundang dan hadir pada kegiatan Pengabdian kepada Masyarakat ini antara lain Ketua dan Bendahara Persatuan Pedagang Pasar Kota Gresik (PPPKG), perwakilan UPT. Pasar Kota Gresik, mitra utama toko Sumber Rejeki (alat dan perlengkapan dapur) dan 2 tambahan perwakilan pedagang Pasar Kota Gresik yakni toko Bunga Kertajaya (bunga hias sintetis) dan toko Bahari (baju gamis dan dewasa). Berikut tahapan kegiatan Pengabdian kepada Masyarakat yang ditunjukkan pada Gambar 1.

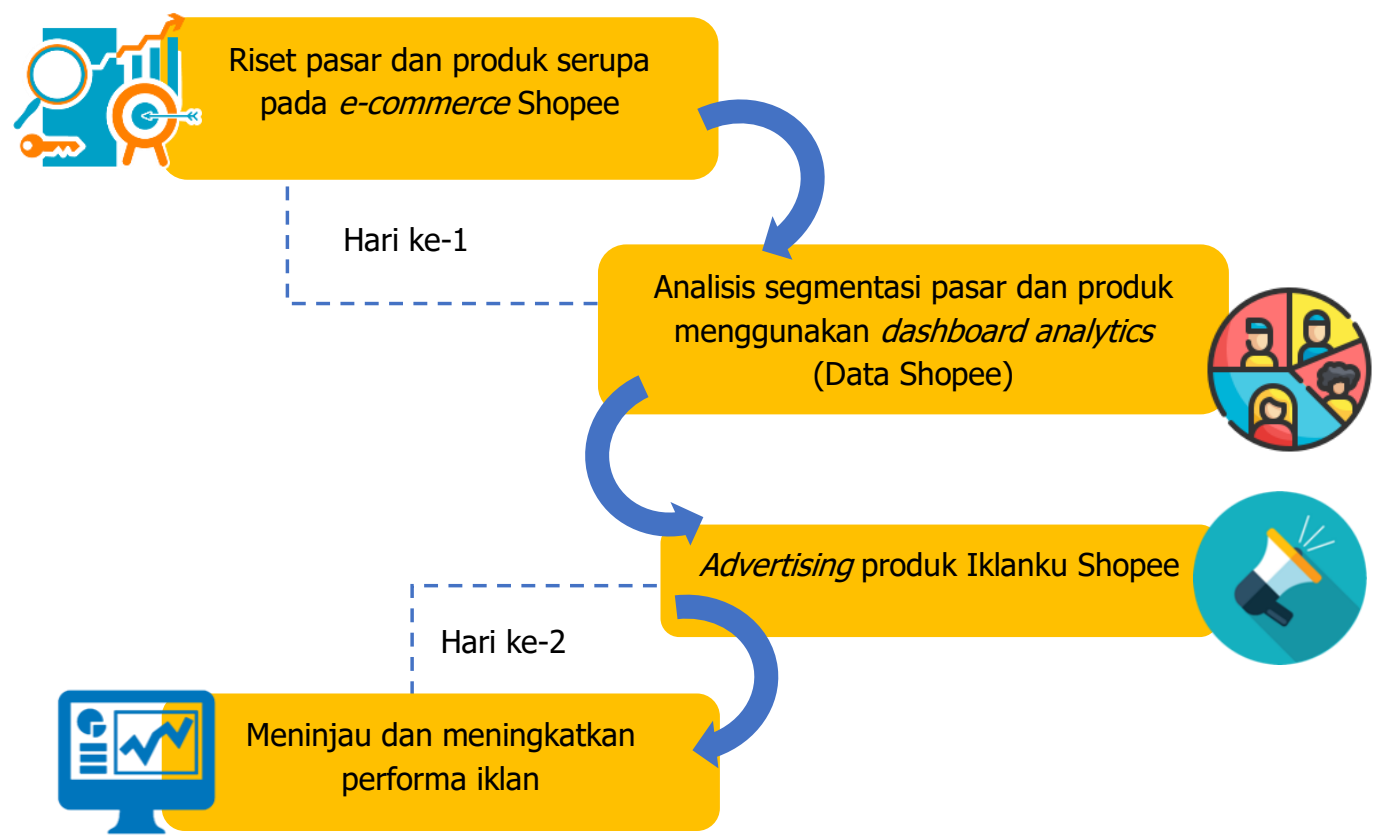

Gambar 1. Tahapan kegiatan pengabdian kepada masyarakat dengan mitra pedagang

Kegiatan hari pertama yang dijadwalkan membahas dua topik yakni riset pasar dan analisis segmentasi pemasaran produk pada marketplace Shopee tanggal 6 Juli 2021 harus dilakukan secara daring menggunakan Zoom Meeting karena diberlakukannya PPKM darurat secara nasional. Kemudian dilanjutkan dengan praktik langsung riset pasar dan analisis segmentasi pemasaran produk terhadap beberapa pesaing yang menjual barang sejenis oleh masing-masing pedagang yang mengikuti kegiatan ini. Penyampaian materi kedua yakni advertising produk, peninjauan dan peningkatan performa iklan pada marketplace Shopee dilaksanakan pada tanggal 9 Juli 2021 secara daring melalui Zoom Meeting. Bersamaan dengan pemaparan terkait materi advertising produk, maka dilakukan pembahasan terkait hasil riset pasar dan analisis segmentasi pemasaran produk yang telah dilakukan oleh masing-masing pedagang terhadap beberapa pesaing yang menjual produk serupa di Shopee. Untuk mengetahui dampak pemanfaatan fitur advertising di Shopee, maka dilakukan pengamatan dan analisis dari sisi perubahan kunjungan calon pembeli ke lapak para pedagang di Shopee serta transaksi penjualannya. Parameter lain yang diamati adalah respon para pedagang terhadap edukasi terkait pemanfaatan fitur-fitur yang terdapat pada marketplace Shopee.

Kegiatan di luar Zoom Meeting juga dilaksanakan untuk memantau dan mengevaluasi hasil percobaan yang dilakukan oleh para pedagang. Untuk mempermudah komunikasi, pemantauan dilakukan dengan metode group discussion menggunakan Whatsapp Group yang dibagi menjadi tiga grup mengikuti banyaknya pedagang yang menghadiri kegiatan Pengabdian kepada 
Masyarakat. Pemantauan yang pertama yaitu pada saat setelah pemaparan materi tentang riset produk dan analisis segmentasi pemasaran pada tanggal 7-8 Juli 2021. Pemantauan kedua yaitu setelah selesai pemaparan materi tentang advertising produk, peninjauan dan peningkatan performa iklan pada marketplace Shopee, maka dilakukan group discussion untuk memantau dan mengarahkan para pedagang agar dapat memasarkan produk pada iklan marketplace Shopee. Pemantauan ini dilaksanakan selama tiga hari, yaitu pada tanggal 10-12 Juli 2021.

Tabel 1. Rundown pelaksanaan kegiatan pengabdian kepada masyarakat-PIKAT dengan mitra pedagang pasar Kota Gresik

\begin{tabular}{|c|c|c|}
\hline No. & Hari / Tanggal / Pukul & Kegiatan \\
\hline 1. & $\begin{array}{l}\text { Selasa, } 6 \text { Juli } 2021 \\
\text { Pukul } 18.00-20.00 \text { WIB }\end{array}$ & $\begin{array}{c}\text { Zoom Meeting Online (Pelatihan secara Daring) } \\
\text { Topik 1: Riset Produk dan Segmentasi Pemasaran } \\
\text { Produk pada Marketplace Shopee }\end{array}$ \\
\hline 2. & $\begin{array}{l}\text { Rabu-Kamis, } 7-8 \text { Juli } 2021 \\
\text { Pukul } 18.00-20.00 \text { WIB }\end{array}$ & Group Discussion Topik 1 via Whatsapp Group \\
\hline 3. & $\begin{array}{l}\text { Jumat, } 9 \text { Juli } 2021 \\
\text { Pukul } 18.00-20.00 \text { WIB }\end{array}$ & $\begin{array}{c}\text { Zoom Meeting Online (Pelatihan secara Daring) } \\
\text { Topik 2: Advertising Produk, Peninjauan dan } \\
\text { Peningkatan Performa Iklan pada Marketplace } \\
\text { Shopee }\end{array}$ \\
\hline 4. & $\begin{array}{l}\text { Sabtu-Senin, } 10-12 \text { Juli } 2021 \\
\text { Pukul 18.00-20.00 WIB }\end{array}$ & Group Discussion Topik 2 via Whatsapp Group \\
\hline 5. & $\begin{array}{l}\text { Selasa, } 13 \text { Juli } 2021 \\
\text { Pukul 09.00-11.00 WIB }\end{array}$ & $\begin{array}{l}\text { Pelatihan secara Offline (Luring) dengan melihat } \\
\text { kondisi pandemi Covid-10 secara Nasional } \\
\text { Topik 3: Evaluasi Pelatihan Topik } 1 \text { dan } 2\end{array}$ \\
\hline
\end{tabular}

Peninjauan ke lapangan secara luring juga dilakukan pada tanggal 13 Juli 2021 guna memastikan dan melihat secara langsung progress dan hasil riset para pedagang yang sudah dilakukan selama kurang lebih satu minggu. Kegiatan peninjauan secara luring ini diwakili oleh Ketua Tim Pengabdian kepada Masyarakat-PIKAT karena kondisi yang tidak memungkinkan dengan adanya PPKM sehingga menyebabkan anggota lainnya tidak dapat menghadiri kegiatan tersebut. Adapun kegiatan peninjauan secara luring ini dilakukan dengan menerapkan protokol kesehatan yang ketat. Tabel 1 menunjukkan rundown kegiatan Pengabdian kepada MasyarakatPIKAT dengan mitra pedagang Pasar Kota Gresik.

\section{Hasil dan Pembahasan}

Pada pelaksanaan kegiatan Pengabdian kepada Masyarakat yang diselenggarakan tanggal 6-13 Juli 2021 dilakukan secara daring melalui Zoom Meeting dan pendampingan menggunakan Whatsapp Group. Diawali dengan pembukaan dan pemaparan tentang kegiatan oleh ketua tim Pengabdian kepada Masyarakat, yaitu Tresna Maulana Fahrudin, S.ST., M.T dan juga dihadiri anggota tim Pengabdian kepada Masyarakat yakni Made Hanindia Prami Swari, S.Kom., M.Cs. Ketua tim Pengabdian kepada Masyarakat kemudian memperkenalkan pemateri dan anggota yang ikut serta pada kegiatan ini. Materi di sesi pertama yaitu tentang riset pasar dan analisis segmentasi pemasaran produk pada marketplace Shopee yang disampaikan oleh Nine Alvariqati Varqa Ansori (mahasiswa). Materi di sesi kedua yaitu membahas langkah-langkah 
advertising produk iklan kata kunci dan iklan produk serupa pada marketplace Shopee yang disampaikan oleh Risnaldy Novendra Irawan (mahasiswa). dan materi tambahan terkait peninjauan dan peningkatan performa iklan pada marketplace Shopee yang disampaikan oleh Nabila Rizky Amalia Putri (mahasiswa). Setelah penyampaian materi, beberapa pedagang yang menjadi peserta kegiatan diberikan kesempatan untuk sesi tanya jawab kepada tim Pengabdian kepada Masyarakat yang terkait permasalahan yang dialami terutama di masa pandemi Covid-19 saat ini.

Pelaksanaan kegiatan Pengabdian kepada Masyarakat secara luring diselenggarakan pada tanggal 13 Juli 2021 guna melakukan peninjauan secara langsung ke lapangan terhadap para pedagang pasar Kota Gresik yang dihadiri oleh ketua tim Pengabdian kepada Masyarakat, ketua dan bendahara PPPKG, perwakilan UPT Pasar Kota Gresik, dan pedagang. Kegiatan secara luring ini guna mendiskusikan permasalahan yang dihadapi oleh pengelola dan pedagang di Pasar Kota Gresik selama masa pandemi Covid-19 dan ditambah adanya peraturan PPKM Darurat secara Nasional serta tindak lanjut dari kegiatan Pengabdian kepada Masyarakat secara daring sebelumnya. Gambar 2 menunjukkan dokumentasi foto (a) kegiatan saat daring, sedangkan (b) kegiatan saat luring.

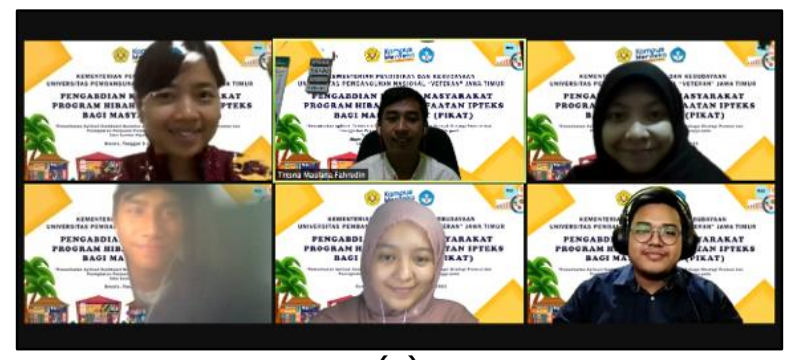

(a)

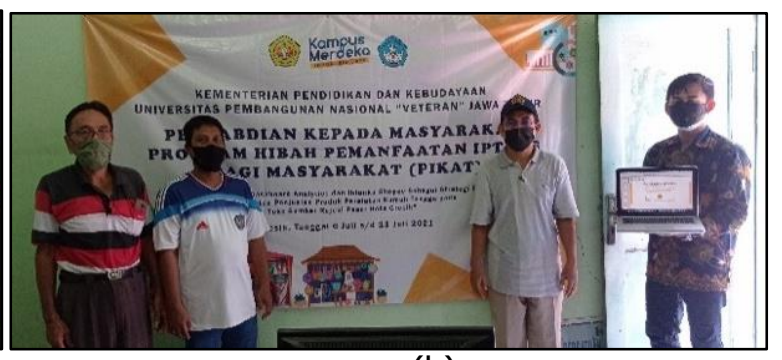

(b)

Gambar 2. (a) Peserta dan Tim Pengabdian kepada Masyarakat saat kegiatan daring, (b) Pada saat kegiatan luring

Penyampaian materi, hasil riset pasar dan analisis segmentasi pemasaran produk, advertising produk, peninjauan dan peningkatan performa iklan dijelaskan sebagai berikut.

\section{Penyampaian Materi Riset Pasar dan Analisis Segmentasi Pemasaran Produk}

Materi yang dibahas pada pertemuan sesi pertama pada tanggal 6 Juli 2021 yakni tentang riset pasar dan analisis segmentasi pemasaran produk pada marketplace Shopee seperti yang ditunjukkan pada Gambar 3, pemaparan materi dilakukan dengan menggunakan slide presentasi yang ditampilkan melalui Zoom Meeting yang kemudian dijelaskan oleh pemateri. Pokok bahasan materi yang dijelaskan pada sesi pertama ini adalah: a) riset pasar, b) metode dan jenis riset pasar, c) langkah-langkah dalam melakukan riset pasar, d) manfaat riset pasar, e) segmentasi pemasaran produk, f) syarat segmentasi pemasaran produk, g) manfaat segmentasi pemasaran produk, h) prosedur segmentasi pemasaran produk, dan i) tutorial riset pasar dan segmentasi pemasaran produk. 

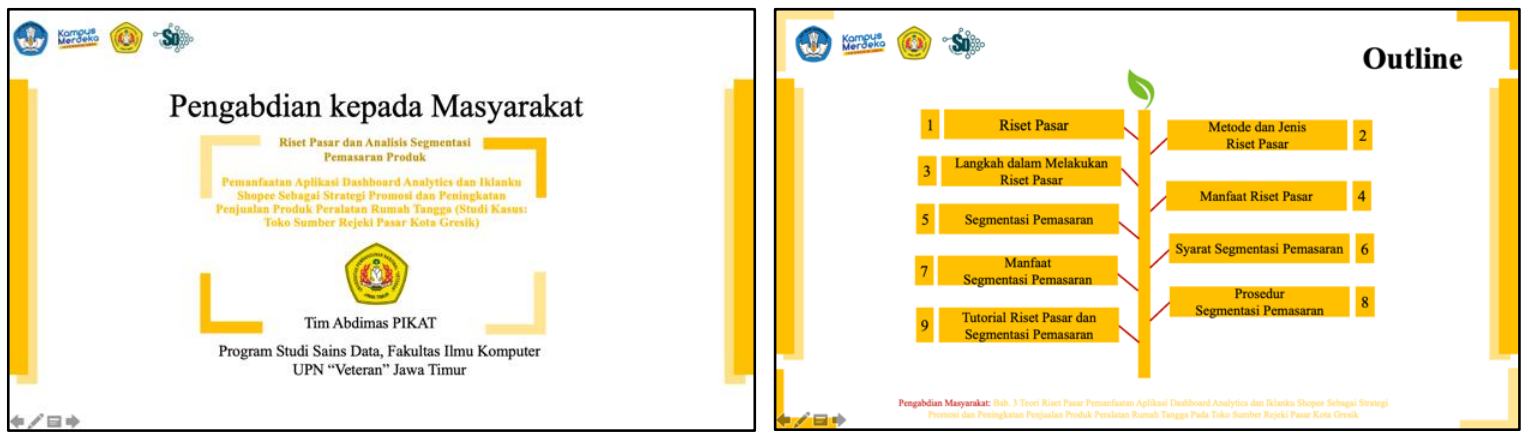

Gambar 3. Materi tentang Riset Produk dan Analisis Segmentasi Pemasaran Produk

Setelah pemateri menyampaikan materi riset pasar dan analisis segmentasi pemasaran produk pada marketplace Shopee, peserta dari pedagang Pasar Kota Gresik diberikan kesempatan untuk tanya jawab mengenai materi terkait. Kegiatan dilanjutkan pada tanggal 7-8 Juli 2021 untuk melaksanakan pendampingan melalui Whatsapp Group agar peserta dapat mempraktikkan materi yang sudah didapatkan. Tim Pengabdian kepada Masyarakat menyiapkan masing-masing sebanyak dua pendamping untuk 1 peserta serta menyiapkan materi yang dibutuhkan oleh peserta. Jika peserta mengalami kesulitan dalam memahami materi yang disampaikan, tim pendamping akan membuka sesi diskusi untuk membahas permasalahan yang sedang dihadapi oleh peserta yang sekiranya dapat diselesaikan dengan materi yang telah disampaikan. Permasalahan yang muncul di awal kegiatan praktik adalah tidak semua peserta dari pedagang Pasar Kota Gresik mahir untuk mengoperasikan aplikasi Shopee sehingga membutuhkan pendampingan secara kontinyu terutama saat pendaftaran akun.

\section{Penyampaian Materi Advertising Produk, Peninjauan dan Peningkatan Performa Iklan}

Setelah pemaparan materi dan pendampingan sesi pertama materi selesai, dilanjutkan pemaparan materi sesi kedua pada tanggal 9 Juli 2021 melalui Zoom Meeting tentang langkahlangkah advertising produk, peninjauan dan peningkatan performa iklan pada marketplace Shopee seperti yang ditunjukkan pada Gambar 4. Pokok bahasan materi yang dijelaskan pada sesi pertama ini adalah: a) pengenalan iklanku shopee, b) tata cara pengisian saldo iklanku shopee, c) mengatur iklan kata kunci beserta langkah-langkahnya, d) mengatur iklan produk beserta langkah-langkahnya dan e) meninjau performa iklan.

Selama penyampaian materi, pemateri berupaya untuk menggunakan pilihan-pilihan kata yang paling mudah untuk difahami oleh peserta dikarenakan tidak semua peserta memiliki background yang sama. Dengan begitu, para peserta diharap mampu memahami materi yang disampaikan dengan mudah dan dapat mempraktikkan langkah-langkah yang dijelaskan oleh pemateri melalui slide presentasi serta menunjukkan hasilnya setelah melakukan proses advertising produk. Hal lain yang harus dilakukan peserta yaitu meninjau performa iklan untuk dilihat dampaknya terhadap barang yang dipasarkan dan dipromosikan menggunakan marketplace Shopee. Sesi tanya jawab juga dibuka saat akhir penjelasan dari materi yang dipaparkan guna memfasilitasi tanya jawab antara pemateri dan peserta. Kegiatan dilanjutkan pada tanggal 10-12 Juli 2021 untuk melaksanakan pendampingan melalui Whatsapp Group agar peserta dapat mempraktikkan materi yang sudah didapatkan. 


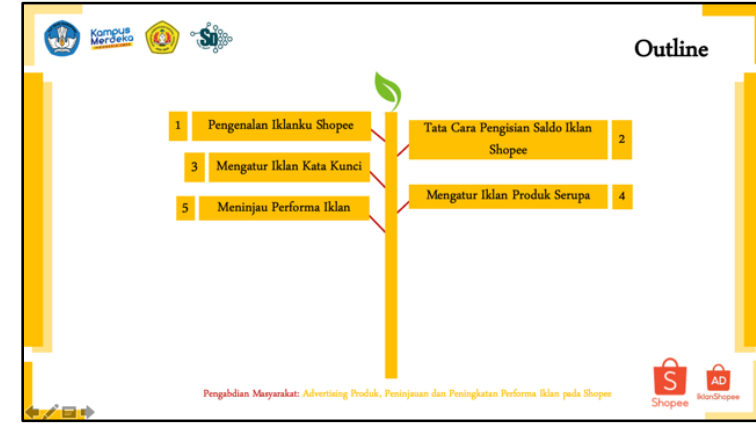

(a)

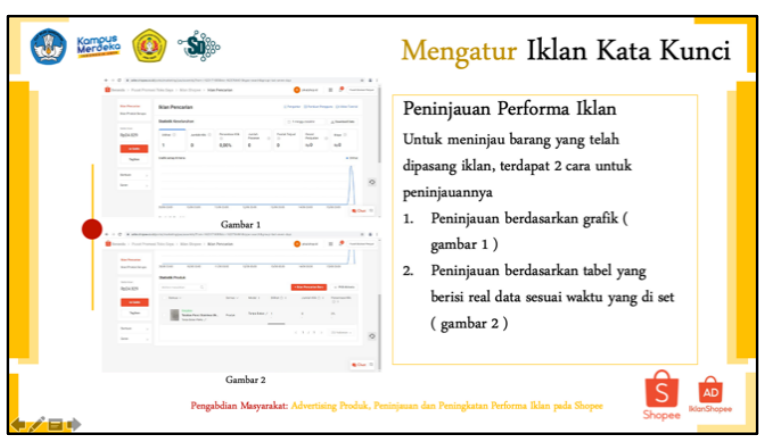

(b)

Gambar 4. (a) Materi tentang advertising produk, (b) Peninjauan dan peningkatan performa iklan Hasil Riset Pasar dan Advertising Produk oleh Mitra Pedagang Pasar Kota Gresik

Setelah pemateri dari tim selesai memaparkan materi dan sesi tanya jawab berakhir, peserta diminta untuk menunjukkan hasil riset pasar dan segmentasi pemasaran produk serta menjelaskan apakah terdapat barang yang sama dengan barang yang dijual di toko masingmasing pedagang baik dari sisi kualitas maupun harga. Peserta juga diminta untuk melakukan proses advertising produk dan peninjauan performa iklan. Selanjutnya, Tim Pengabdian kepada Masyarakat memberikan feedback terhadap hasil yang dikerjakan oleh peserta. Setelah evaluasi selesai, peserta diminta untuk meninjau iklan selang waktu beberapa hari, peninjauan ini untuk melihat tingkat ketertarikan pengunjung atau pembeli sebelum dan sesudah ditayangkannya iklan melalui marketplace Shopee. Gambar 5 merupakan hasil riset pasar dan segmentasi pemasaran produk oleh peserta saat mengikuti kegiatan Pengabdian kepada Masyarakat yang menampilkan hasil dari produk yang serupa di marketplace Shopee. Sementara itu, Gambar 6 menunjukkan hasil peninjauan performa iklan oleh peserta setelah meninjau beberapa hari terkait produk yang telah diiklankan.

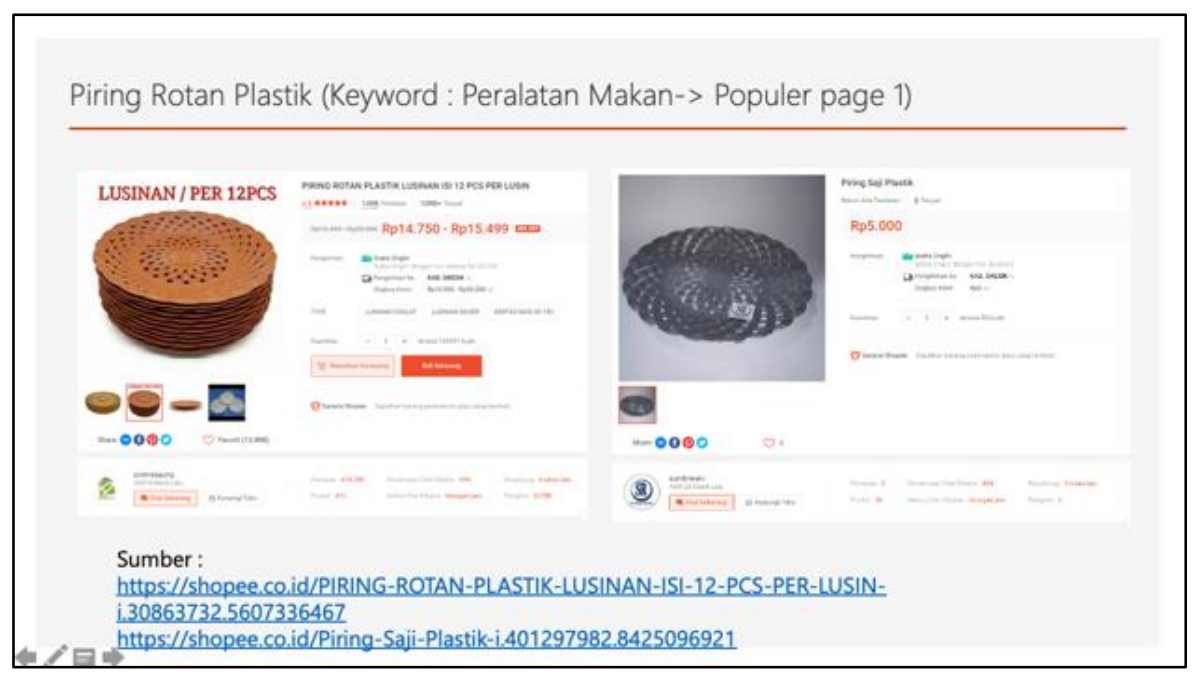

Gambar 5. Hasil Riset Pasar dan Segmentasi Pemasaran Perbandingan Produk Shopee dengan Produk di Toko Milik Pedagang

Berdasarkan Gambar 5, diketahui bahwa terdapat produk yakni piring rotan plastik di toko milik peserta yang mirip dengan produk yang ditawarkan salah satu penjual di marketplace Shopee. Namun, perbedaan signifikan terdapat pada harga yang tertera. Jika diamati secara lebih 
detail, harga yang dipasang oleh penjual lain di marketplace Shopee lebih murah dua atau tiga kali lipat dibandingkan harga di toko milik peserta. Peserta menjual piring rotan plastik dengan harga Rp. 5.000 per biji, sedangkan penjual lain menjual dengan harga Rp. 16.000 per 12 biji (satu lusin). Selain itu, deskripsi produk yang dicantumkan oleh peserta pada toko di marketplace Shopee juga kurang detail untuk menggambarkan kualitas produk, penamaan judul produk terlalu singkat, dan kurangnya upaya untuk mempromosikan produk. Hasil evaluasi terhadap praktik yang telah dilakukan peserta dari Toko Sumber Rejeki yang menjual alat-alat dapur sesudah mengikuti kegiatan Pengabdian kepada Masyarakat dapat dilihat pada Gambar 6. Secara keseluruhan terjadi peningkatan grafik yang cukup signifikan yang menunjukkan pengunjung melihat produk, klik produk, persentase klik, dan beberapa parameter lain pada dashboard analytics Shopee.

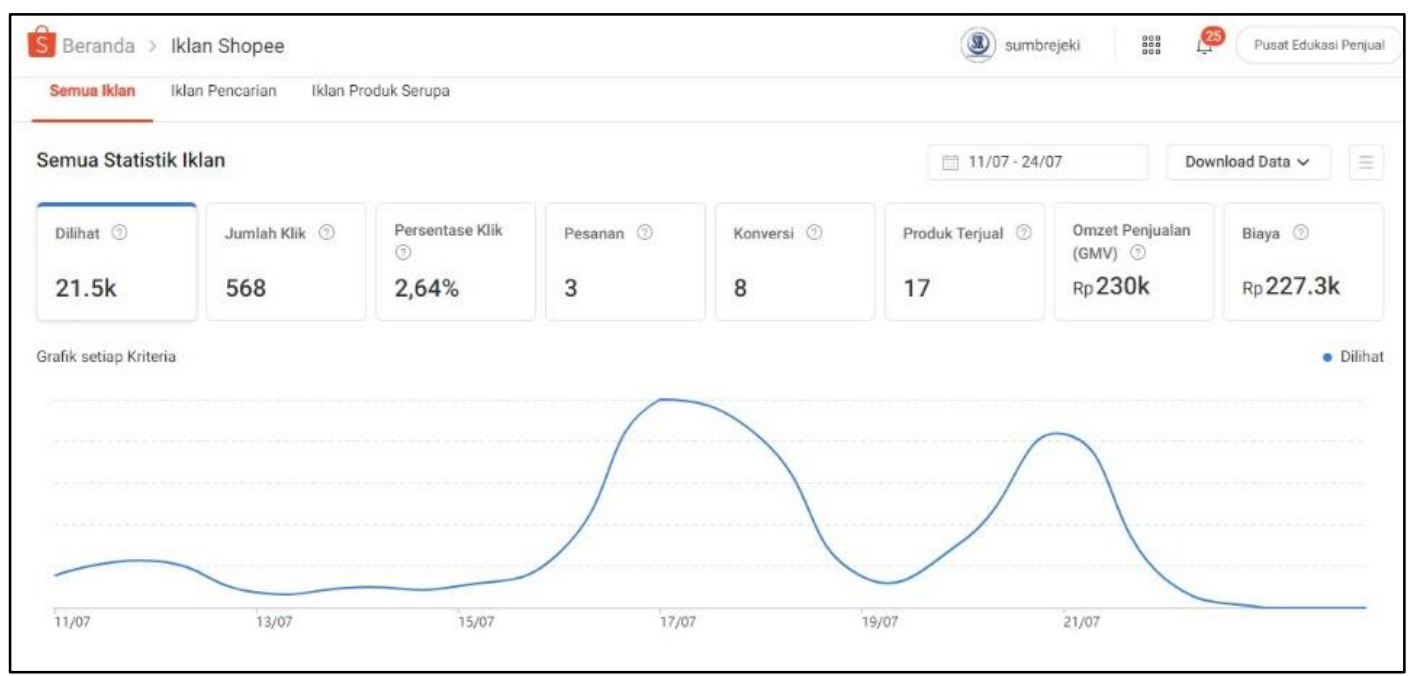

Gambar 6. Hasil Percobaan Pengiklanan Produk Menggunakan Fitur Iklanku Shopee pada Toko Sumber Rejeki Pasar Kota Gresik

Lebih lanjut, Tabel 2 menunjukkan hasil peninjauan secara keseluruhan performa iklan selama 10 hari yang dilaporkan oleh peserta sebagai berikut.

Tabel 2. Hasil Peninjauan Performa Iklan Menggunakan Fitur Iklanku Shopee

\begin{tabular}{lllllll}
\hline No. & \multicolumn{1}{c}{ Nama Iklan } & \multicolumn{1}{c}{ Jenis Iklan } & $\begin{array}{c}\text { Diliha } \\
\text { t }\end{array}$ & $\begin{array}{c}\text { Jumlah } \\
\text { Klik }\end{array}$ & $\begin{array}{c}\text { Persentas } \\
\text { e Klik }\end{array}$ & Biaya \\
\hline 1. & $\begin{array}{l}\text { Alat Panggang Sate } \\
\text { Stainless Steel }\end{array}$ & Iklan pencarian produk & 3608 & 65 & $1.80 \%$ & 12054 \\
2. $\quad \begin{array}{l}\text { [Ukuran Biasa] } \\
\quad \begin{array}{l}\text { Panci/Kukus Ekonomi } \\
\text { Jawa Maspion }\end{array}\end{array}$ & Iklan pencarian produk & 3033 & 123 & $4.06 \%$ & 31416 \\
3. $\quad \begin{array}{l}\text { Sendok Makan Tebal } \\
\text { 4. Iklan pencarian produk }\end{array}$ & 2304 & 138 & $5.99 \%$ & 38838 \\
4. $\quad \begin{array}{l}\text { Tusuk Sate isi 50 }- \\
\text { 250 }\end{array}$ & Iklan pencarian produk & 2196 & 19 & $0.87 \%$ & 3513 \\
5. & Arang Kayu 1 KG & Iklan pencarian produk & 1995 & 19 & $0.95 \%$ & 100792 \\
6. & Pemijat Punggung & Iklan pencarian produk & 1334 & 22 & $1.65 \%$ & 3690 \\
7. & $\quad$ IUkuran Jumbo] & Iklan pencarian produk & 986 & 52 & $5.27 \%$ & 13905
\end{tabular}




\begin{tabular}{|c|c|c|c|c|c|c|}
\hline No. & Nama Iklan & Jenis Iklan & $\begin{array}{c}\text { Diliha } \\
\mathbf{t}\end{array}$ & $\begin{array}{c}\text { Jumlah } \\
\text { Klik }\end{array}$ & $\begin{array}{c}\text { Persentas } \\
\text { e Klik }\end{array}$ & Biaya \\
\hline & $\begin{array}{l}\text { Panci/Kukus Ekonomi } \\
\text { Jawa Maspion }\end{array}$ & & & & & \\
\hline 8. & $\begin{array}{l}\text { Panci Maspion } \\
\text { Yukihira }\end{array}$ & Iklan pencarian produk & 925 & 10 & $1.08 \%$ & 1834 \\
\hline 9. & $\begin{array}{l}\text { Panci Maspion Lucky } \\
\text { Pot Jawa }\end{array}$ & Iklan pencarian produk & 667 & 19 & $2.85 \%$ & 3385 \\
\hline 10. & Cobek Tanah Liat & Iklan pencarian produk & 558 & 27 & $4.84 \%$ & 4135 \\
\hline 11. & $\begin{array}{l}\text { Macam Gelas (Dapat } \\
6 \text { atau } 1 / 2 \text { Lusin) }\end{array}$ & Iklan pencarian produk & 495 & 4 & $0.81 \%$ & 762 \\
\hline 12. & $\begin{array}{l}\text { Cetakan Telur } \\
\text { Tradisional }\end{array}$ & Iklan pencarian produk & 406 & 13 & $3.20 \%$ & 2498 \\
\hline 13. & Cobek Kayu & Iklan pencarian produk & 368 & 6 & $1.63 \%$ & 1121 \\
\hline 14. & Sendok Nasi & Iklan pencarian produk & 353 & 1 & $0.28 \%$ & 188 \\
\hline 15. & $\begin{array}{l}\text { Cetakan Telur Tebal } \\
\text { dan Tutup }\end{array}$ & Iklan pencarian produk & 351 & 13 & $3.70 \%$ & 2557 \\
\hline 16. & $\begin{array}{l}\text { Jepitan Baju atau } \\
\text { Jemuran Merk Lion } \\
\text { Star }\end{array}$ & Iklan pencarian produk & 239 & 3 & $1.26 \%$ & 579 \\
\hline 17. & $\begin{array}{l}\text { Cetakan Kue Pukis } \\
\text { atau Kue Laba-Laba } \\
\text { dan Tutup } \\
\text { Penggoreng }\end{array}$ & Iklan pencarian produk & 217 & 5 & $2.30 \%$ & 922 \\
\hline 18. & Kuas Roti Besar & Iklan pencarian produk & 199 & 4 & $2.01 \%$ & 778 \\
\hline 19. & $\begin{array}{l}\text { Cetakan Jelly Banyak } \\
\text { Bentuk }\end{array}$ & Iklan pencarian produk & 179 & 6 & $3.35 \%$ & 1122 \\
\hline 20. & Piring Saji Plastik & Iklan Produk Serupa & 0 & 0 & $0 \%$ & 0 \\
\hline 21. & $\begin{array}{l}\text { Parutan Bawang } \\
\text { (Pasrahan) }\end{array}$ & Iklan Pencarian Produk & 82 & 82 & $0 \%$ & 0 \\
\hline 22. & Sikat Baju Plastik & Iklan Produk Serupa & 0 & 0 & $0 \%$ & 0 \\
\hline 23. & $\begin{array}{l}\text { Hanger/Kastok Baju } \\
\text { Bunga Tulip (isi 6) }\end{array}$ & Iklan Produk Serupa & 0 & 0 & $0 \%$ & 0 \\
\hline 24. & $\begin{array}{l}\text { Sapu Tangan Orange } \\
\text { Merk Honaga }\end{array}$ & Iklan pencarian produk & 115 & 1 & $0.87 \%$ & 198 \\
\hline 25. & Spatula Solet Besar & Iklan pencarian produk & 93 & 1 & $1.08 \%$ & 121 \\
\hline
\end{tabular}

Adapun perbandingan lainnya yang dapat diamati setelah pelaksananaan kegiatan Pengabdian kepada Masyarakat ini adalah saat peninjauan melalui akun Shopee Seller pada menu Iklan Shopee. Pada Gambar 7 diketahui bahwa grafik yang ditampilkan mengacu pada parameter statistik iklan yang dapat dengan mudah dipantau oleh penjual atau pemilik toko. Statistik iklan ini tentunya sangat menunjang progress untuk peninjauan performa dari total produk yang dipasarkan sejumlah 60 jenis barang, terdapat hampir $50 \%$ barang yang dilihat dan dikunjungi oleh pengguna Shopee. Faktor lain yang dapat mempengaruhi barang dapat ditinjau oleh pengguna adalah dari jenis iklan yang digunakan, peserta yang mengikuti kegiatan ini sebagian besar mempromosikan produknya menggunakan metode iklan pencarian kata kunci. Setelah mengikuti Pengabdian kepada Masyarakat ini, pemantauan juga tetap dilakukan dan 
terdapat lagi perkembangan yaitu beberapa produk laku terjual seperti yang ditunjukkan pada Gambar 6 di dasbor statistik iklan tepatnya pada parameter Produk Terjual.

Grafik yang ditunjukkan pada Gambar 7 merupakan grafik yang menunjukkan data keseluruhan saat dilakukan pemasaran produk menggunakan fitur Iklanku Shopee. Hampir semua produk yang dipromosikan terjadi peningkatan pengunjung dan jumlah produk dilihat secara signifikan. Statistik iklan yang ditunjukkan merupakan summary dari statistik iklan produk secara garis besar sehingga data yang ditampilkan tidak mendetail secara keseluruhan seperti data statistik yang terinci dalam bentuk tabel. Namun, kelebihannya statistik iklan ini dapat mempermudah pengguna dalam melihat performa iklan secara langsung dalam bentuk angka maupun visual grafik.
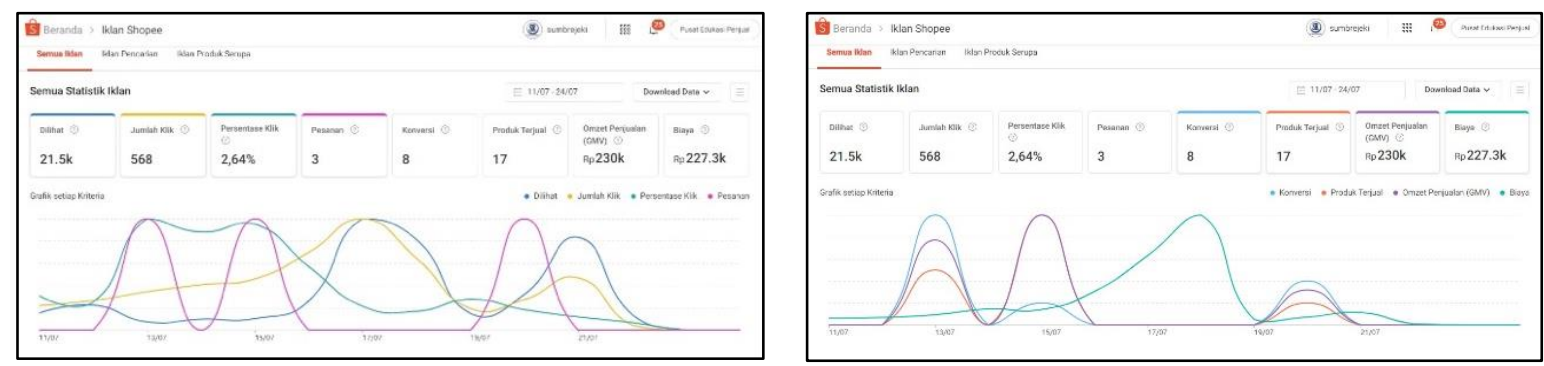

Gambar 7. Peninjauan Performa Berdasarkan Statistik Iklan pada Dasbor Iklanku Shopee

Berdasarkan uraian di atas dapat disimpulkan bahwa kegiatan Pengabdian kepada Masyarakat yang telah dilaksanakan mampu meningkatkan performa penjualan peserta dalam menggunakan marketplace Shopee dengan efektif, yaitu dengan meningkatnya jumlah minat pengunjung produk yang dipasarkan. Persentase peningkatan pengunjung yang terbesar adalah sebesar 5,99\% atau setara dengan 2304 kali dilihat dan 138 kali jumlah klik terhadap salah satu barang yang dipasarkan yakni sebanyak 15 sendok makan tebal stainless stee/terjual.

Persentase peningkatan pengunjung, produk yang dilihat dan jumlah klik pada produk lainnya yakni panci kukus ekonomi ukuran biasa dan jumbo, cobek tanah liat, cetakan telur tradisional, cetakan telur tebal dan tutup, dan cetakan jelly. Dari data tersebut diketahui bahwa kegiatan Pengabdian kepada Masyarakat yang telah dilaksanakan dapat meningkatkan performa produk untuk dapat dijangkau oleh pembeli. Selain itu, peserta yang sebelumnya kurang memahami dan mengeksplorasi tentang sistem Iklanku Shopee, sudah dapat mempratikkan advertising produk secara mandiri. Hal ini juga didukung materi berupa modul dan slidepresentasi yang telah disusun dengan baik oleh Tim Pengabdian kepada Masyarakat dan instruksi langkahlangkah dengan bahasa yang mudah dipahami bagi peserta agar dapat mempraktikkan langsung materi yang telah disampaikan.

Hasil kegiatan Pengabdian kepada Masyarakat ini sesuai dengan beberapa hasil Pengabdian kepada Masyarakat dari peneliti lainnya, misalnya UD. Aulia Stainless Stee/ Rejotangan Tulungagung yang menjual peralatan rumah tangga seperti produk hanger, sendok, dan garpu menunjukkan bahwa terdapat faktor kekuatan perusahaan yang memengaruhi keberhasilan pemasaran produk Faktor tersebut antara lain saluran distribusi, kepemimpinan, lokasi perusahaan yang strategi, dan harga produk yang bersaing. Faktor peluangnya adalah jumlah 
penduduk, pemanfaatan teknologi informasi, budaya konsumtif, dan pertumbuhan ekonomi daerah (Tirtarani \& Suprajang, 2015). Pemanfaatan martketplace juga menunjukkan hasil yang berdampak signifikan terhadap kenaikan traffic, keuntungan, pemasaran, dan pengembangan usaha (Wilianto, 2020). Digitalisasi pemasaran produk juga mampu meningkatkan omzet hingga $22 \%$ melalui pelatihan pengelolaan administrasi berbasis sistem informasi, perencanaan keuangan berbasis digital, penggunaan aplikasi akuntansi digital, pengelolaan risiko keuangan, dan pembuatan desain kontrol mutu produk inovasi serta media sosial (Laksono, Astuti, Widagdo, \& Iswahyudi, 2021).

Selama pelaksanaan kegiatan Pengabdian kepada Masyarakat ini, terdapat beberapa kendala yang dialami oleh peserta (selain peserta dari Toko Sumber Rejeki) dikarenakan terdapat beberapa peserta kurang mahir dalam mengoperasikan smartphone sehingga harus dilakukan pendampingan secara kontinyu oleh Tim Pengabdian kepada Masyarakat. Selain itu, terdapat juga kendala terkait koneksi internet yang kurang stabil yang dialami peserta disebabkan perbedaan kartu seluler yang digunakan dan lokasi rumah masing-masing peserta. Oleh karena itu, agar tujuan kegiatan tetap terlaksana dengan baik, Tim Pengabdian kepada Masyarakat meminta kepada peserta untuk menyimak dan memahami kembali hasil recording dari pelatihan secara daring dan mempraktikannya secara mandiri serta melihat panduan berupa slide presentasi dan modul. Namun, masing-masing peserta memiliki kemampuan dan tingkat kemahiran dalam mengoperasikan smartphone berbeda-beda sehingga mengakibatkan sebagian peserta harus dibantu secara teknis oleh Tim Pengabdian kepada Masyarakat.

Keterbatasan ruang dan waktu selama masa pandemi Covid-19 dan adanya peraturan PPKM Darurat secara Nasional mengakibatkan pelaksanaan kegiatan Pengabdian kepada Masyarakat menjadi kurang optimal. Diskusi dan tanya jawab secara daring membuat pembahasan materi menjadi kurang mengena terhadap pengetahuan dan pemahaman pedagang serta terbatasnya interaksi antara pedagang secara langsung dimana sebagian dari mereka membutuhkan komunikasi secara luring. Namun, kendala-kendala tersebut tidak mengurangi tujuan kegiatan Pengabdian kepada Masyarakat ini sebagai langkah untuk mengajak para pedagang untuk melek digital, dengan cara melakukan penjualan dan pemasaran produk secara hybridagar mampu bertahan dan tumbuh di tengah masa pandemi Covid-19 ini dan ke depannya.

\section{Kesimpulan}

Berdasarkan kegiatan Pengabdian kepada Masyarakat yang sudah dilaksanakan dapat ditarik beberapa kesimpulan. Pertama, hasil riset pasar dan analisis segmentasi pemasaran produk yang telah dilakukan, terdapat kemiripan produk yang ditawarkan oleh penjual lain di marketplace Shopee dengan produk yang dijual oleh peserta dari Toko Sumber Rejeki Pasar Kota Gresik. Hal ini menjadi peluang bagi penjual agar dapat bersaing secara kompetitif di marketplace dari sisi harga dan kualitas produk yang ditawarkan untuk dapat menarik minat pengunjung membeli produk. Kedua, Metode advertising produk pada marketplace Shopee yang sudah dipraktikkan oleh peserta dari Toko Sumber Rejeki Pasar Kota Gresik yang menjual alat-alat dapur dapat meningkatkan jangkauan produk kepada pelanggan secara signifikan dibandingkan tanpa 
menggunakan fitur iklan. Selain itu, dashboard analytics dan statistik iklan Shopee dapat membantu untuk meninjau jumlah pengunjung, jumlah klik, persentase klik hingga 5,99\% pada suatu produk. Dalam melakukan riset dan eksperimen pemasaran produk terdapat cukup banyak metode yang dapat dilakukan untuk dapat menjangkau lebih banyak pengunjung sehingga perlu dilakukan peninjauan secara berkala terhadap riset produk dan performa iklan yang sudah dilakukan. Rekomendasi pada kegiatan yang telah dilaksanakan yaitu mitra perlu mengatur harga produk yang kompetitif, deskripsi produk yang jelas, klaim kualitas produk, variasi produk yang ditawarkan dan menentukan besaran saldo iklan untuk mempromosikan produk pada marketplace Shopee.

\section{Ucapan Terima Kasih}

Penulis mengucapkan terima kasih kepada Kementerian Pendidikan, Kebudayaan, Riset dan Teknologi Universitas Pembangunan Nasional "Veteran" Jawa Timur yang telah mendanai program Abdimas ini berdasarkan Surat Perjanjian Penugasan Dalam Rangka Pelaksanaan Program Pengabdian kepada Masyarakat Dana Internal Batch II untuk Skema Pemanfaatan IPTEKS bagi Masyarakat (PIKAT) Universitas Pembangunan Nasional "Veteran" Jawa Timur Tahun Anggaran 2021, Nomor: SPP / 79 /UN.63.8/DIMAS/V/2021.

\section{Referensi}

Amaludin, I. (2020). Strategi Promosi yang Diterapkan pada PT Shopee Indonesia. Yogyakarta: Program Studi Manajemen Program Diploma III Fakultas Bisnis dan Ekonomika Universitas Islam Indonesia.

Amri, A. (2020). Dampak Covid-19 Terhadap UMKM di Indonesia. Jurnal Brand, 2(1), 123-130.

Astuti, W., Hulaify, A., \& Budi, I. S. (2019). Strategi Ekonomi di Tengah Pandemi Covid-19 Menurut Perspektif Manajemen Strategi Syariah (Studi Fenomenologi Pada Pedagang Pasar Sentra Antarsari Kota Banjarmasin). Banjarmasin: Fakultas Studi Islam, Universitas Islam Kalimantan.

Kementerian Perdagangan. (2020). Pemulihan Aktivitas Perdagangan yang Dilakukan pada Masa Pandemi Corona Virus Disease 2019 (Covid-19) dan New Normal. Jakarta: Kementerian Perdagangan Republik Indonesia.

Laksono, F. A., Astuti, S. D., Widagdo, A., \& Iswahyudi, S. (2021). Peningkatan Kemampuan Digitalisasi Promosi dan Pemasaran Produk Kelompok Eks-buruh Migran di Kabupaten Wonosobo. Transformasi: Jurnal Pengabdian Masyarakat, https://doi.org/10.20414/transformasi.v17i1.2867

Maulana, R. (2021). Peningkatan Penggunaan E-Commerce disaat Pandemi CoVid-19 (Artikel web). Diakses di www.kompasiana.com: https://www.kompasiana.com/rizkymaulanaalfariz/ 5ff1fcb18ede483f8763f115/peningkatan-penggunaan-e-commerce-disaat-pandemi-covid-19

Muhtarom, A. (2018, November). Participation Action Research dalam Membangun Kesadaran Pendidikan Anak di Lingkungan Perkampungan Transisi Kota. Dimas, 18(2), 259-278. DOI: $10.21580 / \mathrm{dms} .2018 .182 .3261$

Pakpahan, A. K. (2020). COVID-19 dan Implikasi Bagi Usaha Mikro, Kecil, dan Menengah. Jurnal I/miah Hubungan Internasional, Edisi Khusus, 59-64. https://doi.org/10.26593/jihi.v0i0.3870.59-64

Panjaitan, C. L., Katiandagho, T., \& Pangemanan, L. (2021). Analisis Pendapatan Pedagang Sayur sebelum dan selama Masa Pandemi Covid-19 di Pasar Lakessi Kota Parepare Sulawesi Selatan. Journal of Agribusiness and Rural Development (Jurnal Agribisnis dan Pengembangan Pedesaan), 2(4), 316-323. 
Transformasi: Jurnal Pengabdian Masyarakat, Vol. 17, No. 2, Desember 2021: 136-150

Rakib, M., Syam, A., Marhawati, \& Dewantara, H. (2020). Pelatihan Merancang Bisnis Online di Masa $\begin{array}{llll}\text { Pandemi bagi } & \text { Mahasiswa. } 2(2), & 129-134 .\end{array}$ https://doi.org/10.26858/dedikasi.v22i2.16121

Rosmadi, M. L. (2021). Inovasi dan Kreativitas Pelaku Usaha UMKM di Era Covid-19. Jurnal IKRA-ITH Ekonomika, 4(2), 87-94.

Soba, H. (2020). Digitalisasi Cegah Klaster Covid-19 Pasar Tradisional (Artikel web). Diakses di www.beritasatu.com: https://www.beritasatu.com/megapolitan/685509/digitalisasi-cegahklaster-covid19-pasar-tradisional

Soetjipto, H. N. (2020). Ketahanan UMKM Jawa Timur Melintasi Pandemi COVID-19. Yogyakarta: KMedia.

Sugianti, Y., \& Sitorus, O. F. (2021). Eksistensi ritel tradisional masa pandemi covid 19. Jurnal Pendidikan Ekonomi : Jurnal IImiah IImu Pendidikan, IImu Ekonomi, dan IImu Sosial, 15(1), 7281. DOI: https://doi.org/10.19184/jpe.v15i1.19315

Supriyadi, Istanti, N., \& Erlita, Y. D. (2021). Perilaku Protokol Kesehatan Covid-19 Pada Pedagang Pasar Tradisional. Jurnal Keperawatan, 13(1), 267-274.

Timorria, I. F. (2020). Transaksi Shopee Naik 130 Persen, Raja E-Commerce Indonesia? (Web artikel). Diakses di https://ekonomi.bisnis.com/read/20200901/12/1285887/transaksi-shopee-naik-130persen-raja-e-commerce-indonesia

Tirtarani, D. O., \& Suprajang, S. E. (2015). Peralatan Rumah Tangga UD. Aulia Stainless Steel Rejotangan Tulungagung. Riset Mahasiswa Ekonomi (RITMIK), 2(3), 301-323.

Wilianto. (2020). Implementasi Strategi Pemasaran Melalui Sosial Media dan Review Produk pada Martketplace Shopee pada Perusahaan Mini Grosir Mall. Conference on Business, Social Sciences and Innovation Technology, 1(1), 287-296.

Wiryawan, I. W., Putra, I. G., \& Dewi, N. P. (2019). Pemberdayaan Pedagang Pasar Seni Guwang yang Berwawasan Teknologi Informasi dan Ramah Lingkungan. Jurnal Bakti Saraswati, 08(01), 20-26. 